\title{
THE EFFECT OF TIME CONSTRAINT ON STUDENT READING COMPREHENSION TEST PERFORMANCE IN NARRATIVE TEXT
}

\author{
${ }^{1}$ Feny Martina, ${ }^{2}$ Syafryadin, ${ }^{1}$ Lisa Rakhmanina, ${ }^{3}$ Sisma Juwita
}

\author{
${ }^{1}$ English Lecturer, English Language Education, IAIN Bengkulu \\ ${ }^{2}$ English Lecturer, Universitas Prof. Dr. Hazairin (UNIHAZ), Bengkulu, Indonesia \\ ${ }^{3}$ English Lecturer, English Language Education, University of Bengkulu, Indonesia \\ Corresponding email: syafryadin@unib.ac.id
}

\begin{tabular}{|c|c|}
\hline Article Info & Abstract \\
\hline $\begin{array}{l}\text { Article History } \\
\text { Received: June } 2020 \\
\text { Revised: July } 2020 \\
\text { Published: July } 2020\end{array}$ & $\begin{array}{l}\text { The objective of this study was to know whether there is any effect between the } \\
\text { time constraints of students when doing exams using (extended time) with } \\
\text { students who take exams using (non-extended time). The sample used in this study } \\
\text { amounted to } 60 \text { grade } 11 \text { students in SMA } 03 \text { Kaur. The method used in this }\end{array}$ \\
\hline $\begin{array}{l}\text { Keywords } \\
\text { Time constraint; } \\
\text { Reading Comprehension; } \\
\text { Narrative text; }\end{array}$ & $\begin{array}{l}\text { research was the quantitative method and uses ex post facto design. In collecting } \\
\text { data the author gives multiple-choice exam questions consisting of } 50 \text { questions, } \\
\text { these are questions in the form of narrative texts. In analyzing the data, the } \\
\text { authors used the Mann Whitney U-Test in SPSS 16.0. The results of this study } \\
\text { indicate that the influence of time constraints on student examinations using } \\
\text { extended time. }\end{array}$ \\
\hline
\end{tabular}

How to cite: Martina, F., Syafryadin, Juwita, S., \& Rakhmanina, L. (2020). The effect of time constraint on student reading comprehension test performance in narrative text. JOLLT Journal of Languages and Language Teaching, 8(3), 323-329, DOI: https://doi.org/10.33394/jollt.v\%vi\%i.2625

\section{INTRODUCTION}

There are four basic skills of English which students at schools or universities are demanded to have good abilities at, they are listening, reading, speaking, and writing (Harmer, 2007). Each of those skills is very important, especially reading because students receive all information (Wibowo, et al., 2020; Rahmawati, 2018). It is in line with Sulistyo (2011) and Tarigan (2008) who stated that reading is a channel of language processing which stores the information. While, reading comprehension is the ability of the reader to recite the contents of the argumentation, expository, or read a description of a particular topic. Besides, reading comprehension refers to the reader's understanding of the text (Razak, 2009; Mulyati, et al, 2007). Some factors that cause the learners faced difficulties in understanding the text, such as lack of vocabulary, less grammatical understanding, an inadequate background of knowledge, and anxiety (Haerazi \& Irawan, 2020; Notion, 2009).

Some relevant researches were conducted by researchers about reading comprehension. Several relevant pieces of research examined the technique, method, or strategy in reading comprehension. The result of their findings showed that those strategies or techniques could increase the students' reading comprehension ability (Wibowo, et al. 2020; Aprilia, 2015; Dhillon, et al. 2020; Rahmawati, 2018; Papatga \& Ersoy, 2016). Besides, the relevant research was also about the correlation between reading comprehension and vocabulary (Ma $\&$ Lin, 2015). Those previous studies were different from the current research because the current research examined the time constraint on reading comprehension test performance in narrative text.

Researchers did not only look for the relevant research but also did an observation in the school field of students, the researchers found out that the students experienced some level of anxiety when the teacher told them that there were a few minutes left to finish their 
worksheet. This condition drove them to put the answer as fast as possible without looking at the questions anymore. Some students even complained a lot since the very first minute of when the exam was started because of the availability of the time given to them. Moreover, some students spent a lot of time on one part of the paragraph because they did not fully understand the text because there were words they were not familiar with. It was in keeping with Haerazi, Vikasari, and Prayati (2019) who state that students face difficulties to understand a text if they do not have enough bcakground knowledge of the text. This caused them to waste time by doing so. Further, based on the interview there were answers that the researcher got, they are: (1) Students have a limited number of words that make it difficult for students to understand narrative texts, (2) Students get into trouble for the difficulty of stories from narrative texts. Schematic stories are hard to read, (3) Students do not feel comfortable or relaxed in reading activities in class when the test is caused by lack of time, and (4) The teacher uses methods that make students happy in reading activities and they do not have the motivation to read.

Related to the previous studies and observation, the researchers did research that aimed to know further about the effect of time constraint or time restriction on the students' test performance in narrative text. According to McGrath, most of the standardized tests given today have a predetermined time or agreed time limit, the deadline provided for this question is for all questions that answer the question by answering the test calmly and without haste.

\section{RESEARCH METHOD \\ Research Design}

Researchers used the Ex Post Facto namely this type of the research is to identify cause and effect relationship, research design which was used to determine the effect of time constraints on students' ability to work on reading test questions. This study used a quantitative design that manages data in the form of numbers, and data processing is carried out using statistical methods (Creswell, 2015). There is no treatment in this ex post facto design. In addition to collecting data, this study also discussed the effect of time constraint non-extended time (standard time limit) and extended time for students in Kaur 03 High School when working on exam questions.

\section{Population and sample}

The population of this study was 210 students at $11^{\text {th }}$-grade students of SMA N 03 Kaur. However, the sample of this study was two classes which consisted of 30 students in every class. The sampling technique of this study was a random sampling technique because of the homogeneity of students' skill ability.

\section{Instrument}

The instrument of this study was the reading test. The reading test was given to measure the students' reading ability for those classes by using those techniques. The test was 65 multiple choices that given to samples. The test was given based on the materials.

\section{Data Collection Technique}

The procedures of collecting the data were the researchers gave a reading test to the research sample which was 11th-grade students at SMA 03 Kaur. To see whether there is an influence on students who work on problems by using a time constraint strategy. Before distributing reading test questions (multiple choice questions) to the research sample, multiple-choice questions were tested for validity using SPSS 16.0 software. which the validity test was done at SMAN 03Kaur, given to 30 students. the number of questions is 65 . The validity test aims to measure the extent to which the instrument is suitable for testing what would be tested. Before distributing test readings to the research sample, the researcher 
must test the validity to measure whether the instrument is suitable for distribution at the time of the study.

\section{Data Analysis}

The data of this research were analyzed quantitatively by using computer software or SPSS. All the calculations, such as mean score, standard deviation, and other calculations were through SPSS. This computer software use made easy researchers calculate the significance. All the data analysis were adapted from Ary \& Ravazieh (2010) and Creswell (2015).

\section{RESEARCH FINDINGS AND DISCUSSION Research Findings}

Table 1

Scores of Reading Comprehension Performance Test for Group 1 Dan Group 2

\begin{tabular}{lccccc}
\hline \multicolumn{1}{c}{ Classes } & N & Mean & Std. Deviation & Max Score & Min. Score \\
\hline Grup 1 (Extended Time) & 30 & 74.067 & 11.633 & 92 & 44 \\
\hline Grup 2 (Non Extended Time) & 30 & 65.533 & 14.982 & 90 & 36 \\
\hline
\end{tabular}

In Table 1, the data represent the strategy time constraint (extended time) that's the highest score of students who were tested using an extension of time is 92 and the lowest score is 44 . It is undeniable that there is a significant difference between the grades of the test using extended time by looking at the highest and lowest scores. then from the mean value of 74,06 , it means that the average value obtained by students is like a table, table 4.1 also shows that the standard deviation is 11, 63 and the variance is 139.95. all descriptive statistics are calculated using SPSS 16. And 2 which represents time constraints (non-extended time). different from the test scores that use extended time. the test using the standard time limit (non-extended time) the highest score is 90 while the lowest score is 36, it can be concluded that there is a significant difference between the tests that use Extended time and nonextended time, when seen from the average value table using non-extended time obtained 65.53 means that the average value of the test using non-extended time (standard time limit) is lower than the test using extended time. Table 4.2 also shows that the standard deviation is 14,983 and variance is 232,198 . All descriptive data are calculated using descriptive statistics SPSS 16.0. 


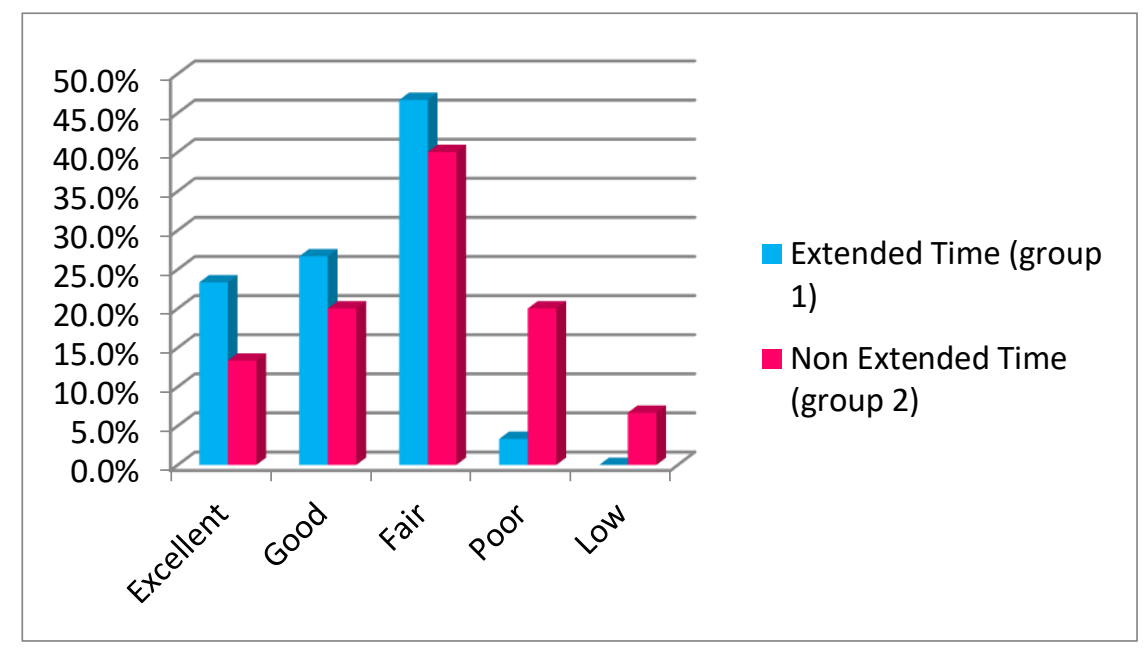

Figure 1. A score of Reading Comprehension Performance Test for Group 1 Dan Group 2

From the diagram and table above, it can be seen the frequency and percentage of students who take the exam using extended time and non-extended time. which was first extended (group), can be seen the frequency and percentage of 30 students. there are $23.3 \%$ who get a score of 100-85 i.e. there are 7 people, then $26.7 \%$ who get a score of $85-75$ there are 8 people, for the percentage of $46.7 \%$, this is the highest percentage where students get more scores in the range this percentage is 75-55 there are 14 people, and for the percentage of $3.3 \%$ score $55-40$ there is 1 student.

Second, is the standard time limit (non-extended time). can be seen in the frequency and percentage of 30 students. there are $13.3 \%$ who get a score of 100-85 i.e. there are 4 people, then $20.0 \%$ who get a score of $85-75$ there are 6 people, for the percentage of $40.0 \%$, this is the highest percentage where students get more scores in the range this percentage is $75-55$ there are 12 people, and for the percentage of $6.7 \%$ score $55-40$ there are 2 students.

Table 2

Mann Whitney U test

\begin{tabular}{lr}
\hline \multicolumn{2}{c}{ Test Statistics $^{\mathrm{a}}$} \\
\hline \multicolumn{2}{c}{ Score_READING } \\
\hline Mann-Whitney U & 300.500 \\
\hline Wilcoxon W & 765.500 \\
\hline Z & -2.214 \\
\hline Asymp. Sig. (2-tailed) & .027 \\
\hline
\end{tabular}

1. Hypothesis

$H_{0}$ : The average reading comprehension test scores of group 1 (extended time) and group 2 (non-extended time) are the same.

$H_{a}$ : The average reading comprehension test scores of group 1 (extended time) and group 2 (non-extended time) are not the same.

2. Criteria area

$H_{0}$ : rejected if the Probability value (Asymp. Sig.) $<0.05$

$H_{a}$ : accepted if the Probability value (Asymp. Sig.) $>0.05$

Because P-value (Asymp. Sig.) $=0.027<0.05$. This means that $\mathrm{H} \_0$ is rejected, so it can be concluded that there is a significant difference in the average reading comprehension performance test scores between group 1 students (extended time) with group 2 (non-extended time). 


\section{Discussion}

According to Bridgement, it was discussed that increasing the time for students who were approved to complete multiple choice exams does not require a large effect on their test results for children as students. So it can be denied that according to the theory above is a measure of time need not be considered on examinations for children or students. McGrath said, Most of the standardized tests given today have a predetermined time or agreed time limit, the deadline provided for this question is for all questions that answer the question by answering the test calmly and without haste. That this research was carried out to provide assistance in learning whether the challenges carried out by students in working on the test questions on the questions given, in the opinion of Chaudrey (1990), time is an important element, a reader needs time in the discussion of ideas. It is time to move on, and revisions must be part of the process. Regarding the deadline and performance of examinees, Elliot and Marquart (2004) have conducted research. The aim of their study was to examine the effect of extended time during testing on the performance.

Inspired by Elliot and Marquart, this research was conducted. This research, carried out at Kaur 03 High School, used 2 different classes randomly selected from class 11. The class taken as research material was 11th grade which will be the subject of this study. They were asked to read types of narrative text readings based on certain topics. Under various test conditions, the standard time limit (90 minutes) and also under the extended time limit (120 minutes).

Based on the table above shows a $U$ value of 300.5 and a $\mathrm{W}$ value of 765.5 If the value of $\mathrm{Z}$ is converted to a magnitude of $-2,214$, with a Probability Value (Asymp. Sig.) Of 0,027 $<0.05$, then $H_{0}$ is rejected, it can be seen whether there is a significant significance based on an average value of 1 (Asymp. Sig.) Of $0,027<0.05$, then $H_{0}$ is rejected, it can be seen whether there is a significant significance based on an average value of 1 . (extended time) with group 2 (not extended time). Because there are significant differences in understanding of group 1 (extended) with group 2 (non-extended time), it can be resolved that the strategic time constraint group 1 (extended time) affect the test of reading comprehension test performance. In brief, this finding of this study showed that the class with extended time could give a significant on students' test performance that could give students the time to think and answer the test correctly. These findings were confirmed to the previous studies that strategies in reading comprehension could improve the students' ability in their reading comprehension (Wibowo, et al. 2020; Aprilia, 2015; Dhillon, et al. 2020; Rahmawati, 2018).

\section{CONCLUSION}

Based on the table above shows a $U$ value of 300.5 and a $\mathrm{W}$ value of 765.5 If the value of $\mathrm{Z}$ is converted to a magnitude of $-2,214$, with a Probability Value (Asymp. Sig.) Of 0,027 $<0.05$, then $H_{0}$ is rejected, it can be seen whether there is a significant significance based on an average value of 1 (Asymp. Sig.) Of $0,027<0.05$, then $H_{0}$ is rejected, it can be seen whether there is a significant significance based on an average value of 1. (extended time) with group 2 (not extended time). Because there are significant differences in understanding of group 1 (extended) with group 2 (non-extended time). ), then it can be resolved that the strategic time constraints group 1 (extended time) affect the test of reading comprehension test performance. In addition, there is an evolution between students taking exams using extended time and students who take exams using non-extended time. it can be concluded that research on time constraint (extended time) has a significant effect on 11th-grade students at SMA 03 Kaur.

Based on the result of this research, the researcher proposed suggestions for the teachers. The researcher suggests the English teacher apply time constraints for students on reading comprehension test performance in working on English exams especially the types of 
questions about narrative texts. For the student, the strategy of making a problem using time constraints is expected that students can enrich the vocabulary in reading and also the matter of getting high scores in working on certain reading problems. For the next researchers, they can conduct similar studies that should understand the problem deeply for better researchers, and assist the students to solve their problems in reading test performance for students.

\section{ACKNOWLEDGEMENT}

The authors wanted to thank all parties who helped the researchers to finish this research. Those were family and my study program.

\section{REFERENCES}

Aprilia, N. (2015). Improving reading comprehension of the eight grade students at SMP N 6 Yogyakarta through POSSE strategy in the academic year 2014/2015. Thesis. English Education Program, State University of Yogyakarta.

Ary, D., Jacobs, L.C, \& Ravazieh, A. (2010). Introduction to Research in Education. Eight Edition. USA: Wadsworth, Cengage Learning.

Carrel, Devine and Eskey, (1988). Interactive Approaches to Second Language Reading. Cambridge, MA: Cambridge University Press.

Coady, J. (1979). A psycholinguistic model of ESL reader. In R. Mackay, B. Barkman, \& R. Jordan (Eds.), Reading in a second language: Hypotheses, organization and practice (pp. 5-12). Rowley, MA: Newbury House.

Creswell, J.W. (2015). Research design: Qualitative, quantitative, and mixed method. Sage Publication.

Dhillon, B.P.S., Herman., Syafryadin. (2020). the effect of skimming method to improve students' ability in reading comprehension on narrative text. Linguist: Journal of Linguistics and language Teaching. 6(1).

Goodman. (1967). Reading: A Physchologilinguistic Game. Journal of the Reading Specialist, 6(1).

Haerazi, H., \& Irawan, L. A. (2020). The Effectiveness of Genre-Based Instructional Model in the Teaching of Writing Skills Viewed from Creativity. Celt: A Journal of Culture, English Language Teaching \& Literature, 20(1). DOI: https://doi.org/10.24167/celt.v20i1.2091

Haerazi, H., May Vikasari, R., \& Prayati, Z. (2019). The use of scientific-based approach in ELT class to improve students' achievement and classroom interaction. Register Journal, 12(2), 157-180. https://doi.org/10.18326/rgt.v12i2.157-180

Harmer, J. (2007). The Practice of English Language Teaching. New York: Longman.

Haynes, M., \& Carr, T. H. (1990). Writing system background and second language reading: A component skills analysis of English reading by native speaker-readers of Chinese. In T. H. Carr \& B. A. Levy (Eds.), Reading and its development: Component skills approaches (pp. 375-418). San Diego, CA: Academic Press.

Krashen, S. D. (1989). We acquire vocabulary and spelling by reading: Additional evidence for the input hypothesis. The Modern Language Journal, 73.

Mulyati, et al. Keterampilan berbahasa SD. Jakarta: Universitas Terbuka.

Ma, Y \& Lin, W. (2015). A study on relationship between English reading comprehension and English vocabulary knowledge. Education research international. 1-15

Notion, S.P. (2009). Teaching ESL/EFL reading and writing. New York: Routledge.

Papatga, E \& Ersoy, A. (2016). Improving reading comprehension skills through the scratch program. International Electronic Journal of Elementary Education. 9(1), 124-150. 
Sandra, S. (1994). Techniques and Resources in Teaching Reading. New York: Oxford American English,

Rahmawati, E. Y. (2018). Analysis of Students' English Reading Comprehension through KWL (Know-Want-Learn) Learning Strategies. International Journal of Language Teaching and Education, 2(3), 238-247. https://doi.org/10.22437/ijolte.v2i3.5641.

Razak, A. (2008). Membaca pemahaman teori dan aplikasi pengajaran. Pekanbaru: Autobiografi.

Snow, C. (2002). Reading for Understanding Toward an R\&D Program in Reading Comprehension. New York: RAND Education.

Sulistyo, G.H. (2011). Reading for Meaning. Malang: Pustaka Kaiswaran

Susetyo. (2010). Statistik untuk Analiis Data Penelitian. PT Refika Aditama .

Tarigan, H.G. (2008). Membaca: Sebagai suatu keterampilan bahasa. Bandung: Angkasa.

Wibowo, Y.E.W., Syafrizal., Syafryadin. (2020). An analysis of English teacher strategies in teaching reading comprehension. JALL (Journal of Applied Linguistics and Literacy). 4(1), 20-27.

Harrison, C. \& Salinger, T. (1998). Assessing Reading 1: Theory and Practice. Routledge. 